\title{
EVALUATION OF BACTERIOCIN-PRODUCING LACTOBACILLUS SAKEI 1 AGAINST LISTERIA MONOCYTOGENES 1/2A GROWTH AND HAEMOLYTIC ACTIVITY
}

\author{
Rafael C.R. Martinez; Elaine C.P. De Martinis* \\ Faculdade de Ciências Farmacêuticas de Ribeirão Preto, Universidade de São Paulo, Ribeirão Preto, São Paulo, Brasil
}

Submitted: October 22, 2004; Returned to authors for corrections: January 27, 2005; Approved: March 28, 2005

\begin{abstract}
Bacteriocin-producing Lactobacillus sakei 1 was cultivated in Brain-Heart Infusion broth $\left(24 \mathrm{~h}\right.$ at $\left.25^{\circ} \mathrm{C}\right)$. The culture supernatant was neutralized, filter sterilized and used to test the activity of bacteriocin against Listeria monocytogenes $1 / 2 \mathrm{a}$, at $8^{\circ} \mathrm{C}$ and $15^{\circ} \mathrm{C}$. Non-bacteriocinogenic Lactobacillus sakei ATCC 15521 was used as a negative control. L. monocytogenes $1 / 2 \mathrm{a}$ was inoculated in culture supernatant medium from $L$. sakei 1 and L. sakei ATCC 15521 and the listerial populations were determined after 0,5 and 10 days. The bacteriocin production was quantified as arbitrary units per $\mathrm{mL}(\mathrm{AU} / \mathrm{mL})$ using agar antagonism test. Additionally, to investigate if $L$. monocytogenes virulence pattern could be changed after bactericion exposure, the ability of $L$. monocytogenes to cause haemolysis in sheep red blood cells was determined, before and after exposure to bacteriocin at $8^{\circ} \mathrm{C}$. In the presence of the antimicrobial peptide, at $8^{\circ} \mathrm{C}, L$. monocytogenes population decreased, but growth of resistant cells was observed. At $15^{\circ} \mathrm{C}$, there was no difference between test and control. Furthermore, the haemolytic activity of $L$. monocytogenes $1 / 2$ a was not altered by exposure to $L$. sakei 1 bacteriocin, which suggests no change in its virulence pattern.
\end{abstract}

Key words: Listeria monocytogenes, Lactobacillus sakei, bacteriocins, virulence, resistance

\section{INTRODUCTION}

Nowadays, consumers demand more "natural" and minimally processed food. As a result, there has been great interest and research on naturally produced antimicrobials, such as the ribosomal peptides, synthesized by lactic acid bacteria (LAB), named bacteriocins (4). These natural antimicrobials present high potential to be applied in hurdle technology, which utilizes synergy of combined treatments to more effectively preserve foods (21).

Among pathogens that can be inhibited by LAB bacteriocins, Listeria monocytogenes is of particular concern to the food industry because of its ability to grow at refrigeration temperatures and its tolerance to preservative agents (19). This bacterium occurs widely in the environment and it has been isolated from a range of sources including vegetables, processed foods, silage and soils (2). L. monocytogenes can cause serious infection in pregnant women, newborn infants, children and adults whose immune systems are weakened (20).

L. monocytogenes produces several virulence factors such as phospholipases, a water soluble hemolysin called listeriolisin O (LLO), a protein (ActA) and several internalins $(13,22)$. LLO is the primary determinant of L. monocytogenes pathogenesis. It aids the bacterial cells to be released from host macrophages, acting as a vacuole-specific lysin and also allows bacterial entrance into the host cytosol $(11,23)$.

Although twelve serotypes of $L$. monocytogenes can cause disease, at least $95 \%$ of the strains isolated from human listeriosis cases belong to three serotypes: $1 / 2 \mathrm{a}, 1 / 2 \mathrm{~b}$ and $4 \mathrm{~b}$ (13). $L$. monocytogenes strains of serogroup 1 have been mainly isolated from foods and serogroup 4 has major association with outbreaks. Nonetheless, Lukinmaa et al. (15) showed that in Finland, cases of listeriosis related to L. monocytogenes serotype 1/2a increased from $22 \%$, in 1990, to $67 \%$ in 2001 and

*Corresponding Author. Mailing address: Faculdade de Ciências Farmacêuticas de Ribeirão Preto, USP, Av. do Café,s/n, 14040-903, Ribeirão Preto, SP, Brasil. Tel: (+5516) 602-4267 - Fax: (+5516) 633-1936. E-mail: edemarti@usp.br 
those caused by L. monocytogenes serotype $4 \mathrm{~b}$ decreased from $61 \%$ to $27 \%$, in the same period.

Interestingly, L. monocytogenes appears to be able to detect specific signals from distinct habitats (warm-blooded animals versus soil and vegetation) and to express or repress specific virulence markers (13). The reason why L. monocytogenes serotype $1 / 2 \mathrm{a}$ is mainly found in food in contrast with $L$. monocytogenes serotype $4 \mathrm{~b}$ being more common in human cases is not completely understood.

Epidemiological data and L. monocytogenes subtyping studies have demonstrated that the pathogen virulence markers are attenuated in all, or at least in the majority of contaminating food strains (13).

In this work, we evaluated the effect of bacteriocin produced by $L$. sakei 1 on growth and virulence marker (haemolytic activity) of L. monocytogenes.

\section{MATERIALS AND METHODS}

\section{Bacterial strains}

Bacteriocin-producing, Lactobacillus sakei 1, belonged to our culture collection (Laboratório de Microbiologia de Alimentos, Faculdade de Ciências Farmacêuticas de Ribeirão Preto - Universidade de São Paulo). The source of this strain was vacuum packed pork sausage $(6,8)$. Lactobacillus sakei ATCC 15521, non-bacteriocin producing, was used as a negative control. Both LAB strains were kept at $-70^{\circ} \mathrm{C}$ in Man Rogosa Sharpe broth (MRS - Oxoid) containing $20 \%$ glycerol.

L. monocytogenes IAL 633, serotype $1 / 2$ a was maintained at $-70^{\circ} \mathrm{C}$, in Brain Heart Infusion broth (BHI - Oxoid) or Trypticase Soy Broth (Oxoid) plus 20\% (v/v) of glycerol (Merck).

\section{Determination of the antilisterial activity of Lactobacillus sakei 1 bacteriocin}

$50 \mathrm{~mL}$ of BHI broth containing ca. $10^{5}$ L. sakei $1 \mathrm{CFU} / \mathrm{mL}$ were incubated for $24 \mathrm{~h}$ at $25^{\circ} \mathrm{C}$ and then centrifuged at $4^{\circ} \mathrm{C}$ at $6,720 \mathrm{~g}$ for 25 minutes (Sorvall RC Plus - Du Pont, USA). The supernatants were neutralized ( $\mathrm{pH} 7.0)$ and then, filter-sterilized through a $0.22 \mathrm{~mm}$ membrane with low capacity of binding proteins (GVWP, Millipore). The filtrates obtained were denominated “L. sakei 1 culture supernatant medium”. For nonbacteriocin producing, L. sakei ATCC 15521, we followed similar procedure.

An overnight culture of $L$. monocytogenes $1 / 2$ a prepared in BHI broth was added $(0.01 \% \mathrm{v} / \mathrm{v})$ to cultures supernatants media of L. sakei 1 and L. sakei ATCC, to yield ca. $10^{5}$ cells of $L$. monocytogenes $/ \mathrm{mL}$. These preparations were incubated at $8^{\circ} \mathrm{C}$ (refrigeration temperature) and at $15^{\circ} \mathrm{C}$ (to simulate temperature abuse). L. monocytogenes populations were enumerated at 0, 5 and 10 days of incubation, by spiral-plating serial decimal dilutions (“Spiral Plater", model D, K \& R Technology, USA) on Tryptone Soy Agar (Oxoid) plus 0.6\% yeast extract (Oxoid) - (TSAYE).
L. sakei 1 bacteriocin was quantified against L. monocytogenes $1 / 2 \mathrm{a}$ in the culture supernatant medium after 0 and 10 days, according to the method of critical dilution (17). Bacteriocin title was defined as the reciprocal of the highest dilution causing a clear zone of inhibition in the indicator listerial lawn and expressed in arbitrary units per $\mathrm{ml}(\mathrm{AU} / \mathrm{mL})$.

To determine if resistant cells to L. sakei 1 bacteriocin had been selected after ten days of bacteriocin exposure, $L$. monocytogenes cells were harvested by centrifugation and washed twice with sodium chloride $0.85 \%$ (w/v) to remove traces of the inhibitory peptide. Those L. monocytogenes cells were used as indicator microorganisms in an additional critical dilution assay performed with a fresh culture supernatant medium.

Three independent replicates of each experiment were done at each temperature.

\section{Evaluation of L. monocytogenes haemolytic activity}

We determined the haemolytic activity of $L$. monocytogenes $1 / 2$ a cells obtained after ten days of exposure to $L$. sakei 1 and L. sakei ATCC culture supernatants media at $8^{\circ} \mathrm{C}$. As a control, we measured the haemolytic activity of $L$. monocytogenes $1 / 2 \mathrm{a}$ from stock. According to Kim et al. (14), optical density studies were performed at $650 \mathrm{~nm}$, comparing differences among hemolyzed and non-hemolyzed samples tested. Three independent replicates were done for each tested condition.

\section{Statistical analysis}

Comparison among test and control groups were performed using three-way analysis of variance (ANOVA). Post-Hoc Tuckey-HSD test for comparing group means (9) was also used. The level of significance was set at $\mathrm{p}<0.05$ for all tests.

Results of haemolytic activity tests were evaluated using $\mathrm{T}$ Student test at the significance level of 5\% (5).

\section{RESULTS}

\section{Assays performed at $8^{\circ} \mathrm{C}$}

Initial counts of $L$. monocytogenes $1 / 2 \mathrm{a}$ in culture supernatant media were of $5.1( \pm 0.1) \log \mathrm{CFU} / \mathrm{mL}$ for both strains (L. sakei 1 and L. sakei ATCC). Bacteriocin activity was quantified as $1,067 \pm 377 \mathrm{AU} / \mathrm{mL}$ in the broth prepared with $L$. sakei 1 . However, spots of growth of L. monocytogenes were noted inside the halos of inhibition of critical dilution assay plates, suggesting the occurrence of survival and/or resistant cells of the pathogen.

After five days of incubation at $8^{\circ} \mathrm{C}, L$. monocytogenes population decreased to $4.0( \pm 0.3) \log \mathrm{CFU} / \mathrm{mL}$ in culture supernatant medium containing the L. sakei 1 bacteriocin. In the negative control, L. monocytogenes $1 / 2$ a reached $6.5( \pm 0.1)$ $\log \mathrm{CFU} / \mathrm{mL}$.

On the tenth day of assay at $8^{\circ} \mathrm{C}, L$. monocytogenes population was $7.2( \pm 0.3)$ in $L$. sakei 1 culture supernatant medium 
and $8.7( \pm 0) \mathrm{CFU} / \mathrm{mL}$ in the control prepared with $L$. sakei ATCC, respectively. Bacteriocin title remained stable $(1,067 \pm 377 \mathrm{AU} / \mathrm{mL})$ in $L$. sakei 1 culture supernatant medium for up to ten days.

L. monocytogenes cells harvest by centrifugation from culture supernatant media after bacteriocin exposure, were used as indicators in an additional test of critical dilution. Bacteriocin produced by $L$. sakei 1 was ineffective against those cells of $L$. monocytogenes.

The L. monocytogenes cells that had been recovered after exposure to bacteriocin of $L$. sakei 1 at $8^{\circ} \mathrm{C}$ were additionally assayed for their haemolytic activity. The results showed there were no statistical differences between test and control (Fig. 1).

\section{Assays performed at $15^{\circ} \mathrm{C}$}

At $15^{\circ} \mathrm{C}$, initial $L$. monocytogenes $1 / 2$ a population was 5.0 $( \pm 0) \log \mathrm{CFU} / \mathrm{mL}$ in L. sakei 1 culture supernatant medium and $5.1( \pm 0.1) \log \mathrm{CFU} / \mathrm{mL}$ for negative control. Title of $1,067 \pm 377$ $\mathrm{AU} / \mathrm{mL}$ was measured for $L$. sakei 1 bacteriocin. However, spots of growth of $L$. monocytogenes inside inhibition halos of critical dilution assay were observed.

On the fifth day of incubation at $15^{\circ} \mathrm{C}, L$. monocytogenes population had sharply increased, regardless the presence of bacteriocin and reached $8.9( \pm 0.1) \log \mathrm{CFU} / \mathrm{mL}$ in L. sakei 1 supernatant medium and $9.0( \pm 0.1) \log \mathrm{CFU} / \mathrm{mL}$ in negative control.

After 10 days, the counts of $L$. monocytogenes remained steady, but the activity of the bacteriocin decreased (533 \pm 189 $\mathrm{AU} / \mathrm{mL}$ ).

Critical dilution assay was also performed with $L$. monocytogenes cells recovered after bacteriocin exposure as indicator. No inhibition was observed, suggesting that a bacteriocin resistant population had been selected.

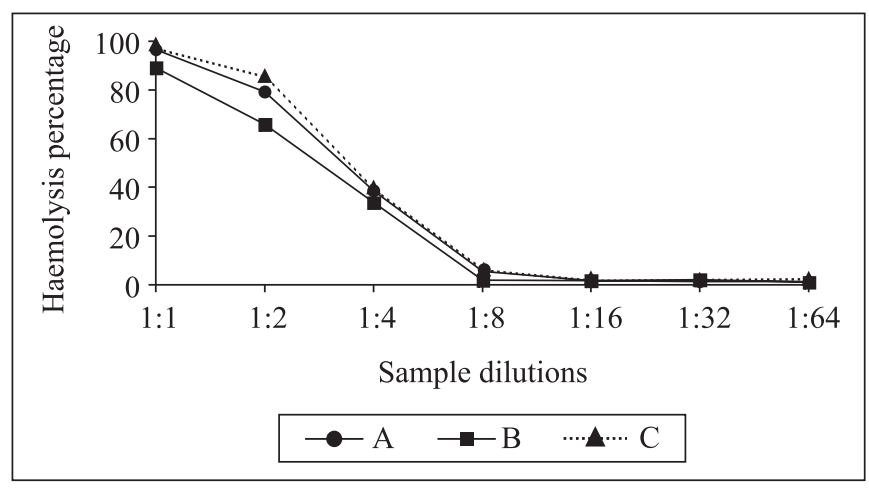

Figure 1. Haemolytic activity of L. monocytogenes $1 / 2$ a towards sheep red blood cells (expressed as hemolysis percentage). A: working-culture of $L$. monocytogenes $1 / 2$ a made from stock; $\mathbf{B}$ : L. monocytogenes $1 / 2$ a recovered from $L$. sakei ATCC 15521 culture supernatant medium incubated at $8^{\circ} \mathrm{C}$ for 10 days and $\mathbf{C}$ : L. monocytogenes $1 / 2 \mathrm{a}$ recovered from $L$. sakei 1 culture supernatant medium incubated at $8^{\circ} \mathrm{C}$ for 10 days.
Statistically significant lower $L$. monocytogenes populations were obtained in the presence of bacteriocin at $8^{\circ} \mathrm{C}$ when compared to the absence of the peptide. However, statistical test showed that, at $15^{\circ} \mathrm{C}$, L. monocytogenes growth was not affected by either LAB bacteriocin after five and ten days of incubation.

\section{DISCUSSION}

Bacteriocin activity was stable in $L$ sakei 1 culture supernatant medium inoculated with $L$. monocytogenes and incubated for ten days at $8^{\circ} \mathrm{C}$, but not after incubation at $15^{\circ} \mathrm{C}$.

In a previous study (16), we tested preparations with $L$. sakei 1 against $L$. monocytogenes $4 \mathrm{~b}$ and the bacteriocin presented higher activity $(12,800 \mathrm{UA} / \mathrm{mL})$. This indicates that $L$. monocytogenes $4 \mathrm{~b}$ was more sensitive to $L$. sakei 1 bacteriocin than $L$. monocytogenes $1 / 2 \mathrm{a}$. Similar results were described by Buncic et al. (3). Those authors evaluated the behavior of $L$. monocytogenes $4 \mathrm{~b}$ and $1 / 2 \mathrm{a}$ strains isolated from clinical and food samples, after exposition to two LABs: $L$. sakei 265 and $L$. sakei 706 . They evidenced that $L$. monocytogenes $4 \mathrm{~b}$ strains, were more sensitive to both bacteriocins when compared to $L$. monocytogenes $1 / 2 \mathrm{a}$. Those authors concluded that $L$. monocytogenes $1 / 2$ a could present competitive advantage over serotype $4 \mathrm{~b}$ in food kept at refrigeration temperature containing bacteriocin-producing LAB as intrinsic microbiota. $L$. monocytogenes serotype $1 / 2$ a would probably survive and surpass $L$. monocytogenes $4 \mathrm{~b}$ growth rates.

In our work, $L$. monocytogenes $1 / 2$ a was recovered after bacteriocin exposure at $8^{\circ} \mathrm{C}$ and $15^{\circ} \mathrm{C}$, and used for critical dilution assay. Under those conditions, it was observed a complete absence of the halos of inhibition. Thus, those bacterial cells were not only survivors but resistant to $L$. sakei 1 bacteriocin. Ennahar et al. (10) tested thirty-one Listeria strains for sensitivity to four class IIa bacteriocins (enterocin $\mathrm{A}$, mesenterocin $\mathrm{Y} 105$, divercin $\mathrm{V} 41$, pediocin $\mathrm{AcH}$ and nisin A) and verified similar antimicrobial patterns ranging from highly susceptible to fully resistant strains, whereas nisin A showed a different pattern in which all Listeria strains were inhibited. Gravesen et al. (12) also verified that $L$. monocytogenes susceptibility to bacteriocins, specially for those belonging to IIa subclass, varied from high susceptibility patterns up to answers of complete resistance of the pathogenic microorganism. These evidences suggest that within a given species and without prior exposure to bacteriocin, resistant $L$. monocytogenes strains to all subclass IIa bacteriocins could naturally occur in the environment (10). Gravesen et al. (12) suggested that the high L. monocytogenes resistance level against IIa bacteriocins class and some Gram-positive bacteria may occur by a common mechanism, which would not be dependent on the bacterial strain, bacteriocin class or environmental tested conditions. 
In the present study, there was no statistical significant change of the haemolytic activity of L. monocytogenes recovered under any condition, after ten days of exposure to 800-1,600 AU/mL L. sakei 1 bacteriocin.

There are few studies available in literature concerning to the possible modification of $L$. monocytogenes haemolytic activity when submitted to adverse conditions, such as antimicrobial substances or co-inoculation with microorganisms presenting inhibitory activity.

McKellar (18) studied the influence of chemical preservatives of food on L. monocytogenes LLO secretion and observed an inhibition of it in the presence of nitrates, sorbates and chloride. It was postulated that the action of these substances in the cytosol of the pathogen altered the production of LLO.

Alves et al. (1) verified a significant reduction of $L$. monocytogenes $4 \mathrm{~b}$ e $1 / 2 \mathrm{a}$ haemolytic activity after exposure to some ingredients present in model food gravies added of the bacteriocinogenic culture L. sakei 1 .

Alves et al. (1) studied the effect of L. sakei 1 bacteriocin produced "in situ" and not the influence of the semi-purified antimicrobial peptide as performed in our assays. The differences observed could be attributed to acid production and to bacterial competition for room, nutrients and oxygen, which could have altered L. monocytogenes strains haemolytic activity. Furthermore, bacteriocins are known to act on the membrane surface of target microorganisms, differently from acid antimicrobials which acts in the cytosol (7).

In conclusion, our results show that $L$. monocytogenes $1 / 2 \mathrm{a}$ was inhibited in the presence of $L$. sakei 1 bacteriocin at $8^{\circ} \mathrm{C}$, but not at $15^{\circ} \mathrm{C}$. In this work, we demonstrated that the use of LAB bacteriocin should be combined with temperature to effectively control $L$. monocytogenes in food systems. Furthermore, LLO expression in L. monocytogenes 1/2a was not altered by exposure to $L$. sakei 1 , suggesting no modification in the pathogen virulence had ocurred.

\section{ACKNOWLEDGEMENTS}

Rafael Chacon Ruiz Martinez is grateful to São Paulo State Foundation for Support of Science (FAPESP, Process \# 02/056722 ) for granting an undergraduate fellowship to do this work.

\section{RESUMO}

\section{Avaliação de Lactobacillus sakei 1 produtor de bacteriocina frente a Listeria monocytogenes 1/2a e sua atividade hemolítica}

Lactobacillus sakei 1 produtor de bacteriocina foi cultivado em caldo Infusão Cérebro-Coração por $24 \mathrm{~h}$ a $25^{\circ} \mathrm{C}$. O sobrenadante da cultura foi neutralizado, esterilizado por filtração e usado para testar a atividade da bacteriocina frente a
Listeria monocytogenes $1 / 2 \mathrm{a}$, a $8^{\circ} \mathrm{C}$ e $15^{\circ} \mathrm{C}$. Lactobacillus sakei ATCC 15521 não bacteriocinogênico, foi utilizado como controle negativo. L. monocytogenes $1 / 2$ a foi inoculada no sobrenadante da cultura de L.sakei 1 e L. sakei ATCC 15521 e as populações listeriais foram determinadas após 0,5 e 10 dias. A produção de bacteriocina foi quantificada como unidades arbitrárias por $\mathrm{mL}$ (UA/mL), utilizando-se o teste de antagonismo em ágar. Adicionalmente, para investigar se o padrão de virulência de $L$. monocytogenes poderia ter mudado após exposição à bacteriocina, foi avaliada a habilidade de $L$. monocytogenes em causar hemólise em hemáceas de carneiro, antes e após exposição à bacteriocina a $8^{\circ} \mathrm{C}$. Na presença do peptídeo antimicrobiano, a $8^{\circ} \mathrm{C}$, a população de $L$. monocytogenes foi reduzida, mas o desenvolvimento de células resistentes foi observado. $\mathrm{A} 15^{\circ} \mathrm{C}$, não houve diferença entre os grupos controle e teste. Além disso, a atividade hemolítica de L. monocytogenes 1/2a não foi alterada pela exposição à bacteriocina de $L$. sakei, o que sugere que não houve mudança em seu padrão de virulência.

Palavras-chave: Listeria monocytogenes, Lactobacillus sakei, bacteriocinas, virulência, resistência

\section{REFERENCES}

1. Alves, V.F.; Lavrador, M.A.S.; De Martinis, E.C.P. Bacteriocin exposure and food ingredients influence on growth and virulence of Listeria monocytogenes in a model meat gravy system. J. Food Saf., 23, 201-217, 2003.

2. Beresford, M.R.; Andrew, P.W.; Shama, G. Listeria monocytogenes adheres to many materials found in food-processing environments. J. Appl. Microbiol., 90, 1000-1005, 2001.

3. Buncic, S.; Sheryl, M.A.; Rocourt, J.; Dimitrijevic, M. Can foodrelated environmental factors induce different behaviour in two key serovars, $4 \mathrm{~b}$ and $1 / 2 \mathrm{a}$, of Listeria monocytogenes? Int. J. Food Microbiol., 65, 201-212, 2001.

4. Cleveland, J.; Montville, T.J.; Nes, I.F.; Chikindas, M.L. Bacteriocins: safe, natural antimicrobials for food preservation. Int. J. Food Microbiol., 71, 1-20, 2001.

5. Daniel, W.W. Biostatistics: a foundation for analysis in the health sciences. John Wiley \& Sons, New York, 1974, p. 123-130.

6. De Martinis, E.C.P. Identification of meat isolated bacteriocinproducing lactic acid bacteria using biotyping and ribotyping. Arq. Bras. Med. Vet. Zoo., 54, 659-661, 2002.

7. De Martinis, E.C.P.; Alves, V.F.; Franco, B.D.G. Fundamentals and perspectives for the use of bacteriocins produced by lactic acid bacteria in meat products. Food Rev. Int., 18(2-3), 191-208, 2002.

8. De Martinis, E.C.P.; Públio, M.R.P.; Santarosa, P.R.; Freitas, F.Z. Antilisterial activity of lactic acid bacteria isolated from vacuumpackaged brazilian meat and meat products. Braz. J. Microbiol., 32, 32-37, 2001.

9. Edwards, A.L. Statistical methods. Holt, Rinehart and Winston, New York, 1967, p. 257-271

10. Ennahar, S.; Deschamps, N.; Richard, J. Natural variation of Listeria strains to class Iia bacteriocins. Cur. Microbiol., 4, 1-4, 2000.

11. Glomski, I.J.; Decatur, A.L.; Portnoy, D.A. Listeria monocytogenes mutants that fail to compartmentilize listeriolysin $\mathrm{O}$ activity are cytotoxic, avirulent, and nable to evade host extracellular defenses. Infect. Immun., 71(2), 6754-6765, 2003. 
12. Gravessen, A.; Rammath, M.; Rechinger, K.B.; Andersen, N.; Jansch, L.; Hechard, Y.; Hastings, J.W.; Knochel, S. High level of resistence to class IIa bacteriocins in associated with one general mechanism in Listeria monocytogenes. Appl. Environ. Microbiol., 148(8), 2361$2369,2002$.

13. Kathariou, S. Listeria monocytogenes virulence and pathogenicity, a food safety perspective. J. Food Prot., 65(11), 1811-1829, 2002

14. Kim, K.; Murano, E.A.; Olson, D.G. Effect of heat shock on production of listeriolysin O by Listeria monocytogenes. J. Food Saf., 14, 273-279, 1994.

15. Lukinmaa, S.; Miettinem, M.; Nakari, U.M.; Korkeala, H.; Sitonen, A. Listeria monocytogenes isolates from invasive infections: variation of sero-and genotypes during an 11-year period in Finland. J. Clin. Microbiol., 41(4), 1694-1700, 2003.

16. Martinez, R.C.R.; De Martinis, E.C.P. Antilisterial activity of a crude preparation of Lactobacillus sakei 1 bacteriocin and its lack of influence on Listeria monocytogenes haemolytic activity. Food Control., 16, 429-433, 2005.
17. Mayr-Harting, A.; Hedges, A.J.; Berkeley, R.C.W. Methods for studying bacteriocins. In: Morres, J.R.; Ribbons, D.W. (eds.) Methods in Microbiology. Academic Press, New York, 1972, p. 313-342.

18. McKellar, R.C. Effect of preservatives and growth factors on secretion of Listeriolisin O by Listeria monocytogenes. J. Food Prot., 56, 380-384, 1993.

19. Norwood, D.E.; Gilmour, A. Adherence of Listeria monocytogenes strains to stainless steel coupons. J. Appl. Microbiol., 86, 576-582, 1999.

20. Rocourt, J.; Jacquet, C.; Reilly, A. Epidemiology of human listeriosis and seafoods. Int. J. Food Microbiol., 62, 197-209, 2000.

21. Stiles, M.E. Biopreservation by lactic acid bacteria. Anton. Leeuw. Int. J. G., 70, 331-345, 1996.

22. Swaminathan, B.; Rocourt, J.; Bille, J. Listeria. Manual of Clinical Microbiology. ASM Press, Washington DC, 1995, p. 341-348.

23. Tiltney, L.G.; Portnoy, D.A. Actin filaments and the growth, movement, and spread of the intracellular bacterial parasite, Listeria monocytogenes. J. Cell. Biol., 109, 1597-1608, 1989. 